\title{
20
}

\section{Stormwater Databases: NURP, USGS, International BMP Database and NSQD}

\section{Alexander Maestre and Robert Pitt}

During the past 30 years government agencies, universities and private companies have invested millions of dollars trying to understand the factors that affect the quality of stormwater discharges. Stormwater can pick up dirt, chemicals, and other pollutants that are then discharged to the stormwater drainage system and ultimately discharged to receiving water bodies, usually without any treatment. According to the U.S. EPA, stormwater is one of the major causes of water quality impairment in the nation's rivers, lakes, ocean shorelines, and estuaries.

In the U.S., several nationwide monitoring efforts have examined the sources and resulting concentrations of stormwater pollutants. Some of the results of these studies have been stored in electronic databases. For example the International Best Management Practices Database (BMP database) uses a database application to store and retrieve information from different stormwater controls. Another example is the National Stormwater Quality Database (NSQD) that stores some of the reported data from the National Pollutant Discharge Elimination System (NPDES) Phase I stormwater monitoring program in a spreadsheet format.

Two previous national stormwater monitoring efforts have included the Nationwide Urban Runoff Program (NURP) finished in 1983 and the USGS urban stormwater database completed in 1987. The results from both of these efforts were stored on magnetic tapes with a proprietary format.

Maestre, A. and R.E. Pitt. 2007. "Stormwater Databases: NURP, USGS, International BMP Database and NSQD." Journal of Water Management Modeling R227-20. doi: 10.14796/JWMM.R227-20.

(C) CHI 2007 www.chijournal.org ISSN: 2292-6062 (Formerly in Contemporary Modeling of Urban Water Systems. ISBN: 0-9736716-3-7) 
The data from these four databases were sorted and combined in this chapter (the NSQD, version 2 beta), which now contains information for about 10,000 individual stormwater events representing all areas of the U.S. This combined database was evaluated to identify significant differences in the concentrations of nine stormwater constituents among land use, geographical region, and season, as an example of the types of evaluations possible. The analyses were performed using the General Linear Model (GLM).

\subsection{Stormwater Databases Description}

The four databases included information about the sampling locations, main land use in the watershed, the sample date, and various other details. The objectives of each database compilation were different, but the information stored for each can be used to describe if there are statistically significant differences among land use, geographical location, season and their interactions. The following sections describe each of the databases included in the analysis.

\subsubsection{The Nationwide Urban Runoff Program (NURP Database)}

The U.S. EPA NURP projects had several objectives: to characterize stormwater pollutants for different land uses throughout the nation, to identify the major sources of the pollutants, to determine the pollutant removal abilities of common stormwater control practices, and to examine receiving water impacts associated with stormwater discharges. A total of 2,300 events in 28 NURP projects at 81 sites were included in the program (USEPA, 1983). The 28 projects were selected based on the type of receiving waters, the hydrologic conditions, urban characteristics, beneficial use of the receiving water, and the recognition of runoff problems.

The results from NURP were stored on magnetic tapes, included in a special section of the EPA STORED database, and also included as a hard copy appendix in the final report. The EPA reports and project reports included site descriptions, basin maps, drainage area descriptions, and best management practice information. One of the main achievements of this program was the definition of Event Mean Concentration (EMC), the ratio between the total constituent mass divided by the total runoff volume for each event. In 1987, the University of Illinois transferred the NURP data to 
electronic files more accessible to personal computers. Many project reports were also prepared by the individual participants that included much more detailed information than was summarized in the EPA summary reports.

The NURP program analyzed the following 10 constituents (known as the standard pollutants): total suspended solids (TSS), 5-day biochemical oxygen demand $\left(\mathrm{BOD}_{5}\right)$, chemical oxygen demand (COD), total phosphorus (TP), soluble phosphorus (SP), Total Kjeldahl Nitrogen (TKN), nitrite plus nitrate $\left(\mathrm{NO}_{2}+\mathrm{NO}_{3}\right)$, total copper $(\mathrm{Cu})$, total lead $(\mathrm{Pb})$, and total zinc $(\mathrm{Zn})$. Fecal coliform bacteria was also included in the NURP program. Some programs also included additional constituents as part of the specific project objectives (such as particle size distributions, and more detailed heavy metal analyses). Also, complete rainfall and runoff data were obtained for each monitored event. About $75 \%$ of the stormwater samples collected in the NURP projects were from the Great Lakes (EPA Rain Zone 1) and Northeast (EPA Rain Zone 2) areas. The EPA rain zones are defined as areas with similar climatic conditions (USEPA, 1986). Figure 20.1 shows the location of the municipalities included in the databases and the EPA rain zones.

\subsubsection{The U.S. Geological Survey Urban-Stormwater Database}

The USGS database stored the stormwater loads and rainfall-runoff characteristics of 97 USGS stations in 21 metropolitan areas in the U.S. (USGS, 1987). A total of 1,144 events were included in this database. The results from the program were stored in magnetic tapes also, and in the WATSTOR database. Projects included in this database examined eighteen constituents, and over fifteen rainfall-runoff characteristics were reported.

Except for $\mathrm{BOD}_{5}$ and SP all the basic constituents included in the NURP database were also included in the USGS urban stormwater database. The database also included additional constituents, including dissolved chloride (DCl), and total cadmium (Cd) amongst others. An important distinguishing characteristic of the USGS urban stormwater database compared to the NURP data is the detailed rainfall-runoff information that was reported. Specifically, the maximum 5, 15 and $60 \mathrm{~min}$. rainfall rates, peak discharge rates, duration of rainfall, and duration of runoff were reported amongst other hydrology characteristics. The drainage basin information was also more complete in the USGS database than the information presented in the EPA summary NURP report (See the individual NURP project reports for more detailed information). The USGS database includes the impervious area in the watershed as the total effective impervious area, the basin slope, 
the conveyance slope, and population density among the 28 basin characteristics stored. Also in the USGS database are more detailed land use classifications (11 separate classifications, compared to the five used in the NURP summary report). The geographical distribution of the stormwater samples presented in the USGS urban stormwater database was also better representative of national conditions, than the NURP database. EPA rain zones $1,2,3,6,7$, and 9 have at least $10 \%$ of the samples in each. Figure 20.1 shows the location of the municipalities included in this database, along with the EPA rain zones divisions.

\subsubsection{The National Stormwater Quality Database (NSQD), v. 1.1}

The NSQD was created using the monitoring results from many NPDES phase I stormwater permit holders. Only information from outfalls was included in the NSQD database, receiving water data is not included. The University of Alabama and the Center of Watershed Protection compiled the results of stormwater samples collected at 360 sites in 65 communities in the continental U.S. A total of 3,765 stormwater events were collected during the duration of the project. More than 100 constituents and 10 land uses were included. The original project stressed the Chesapeake Bay and the Southeastern regions of the U.S. although data from other locations throughout the U.S. were also obtained. A current extension of the project is collecting additional data from the upper Midwest and northeastern portions of the country

All the standard pollutants described in the NURP database were also included in the NSQD database. This database also included many additional constituents including total dissolved solids (TDS), total cadmium (Cd), ammonia $\left(\mathrm{NH}_{3}\right)$, oil and grease $(\mathrm{O} \& \mathrm{G})$, and arsenic (As), among others.

The NSQD database includes a series of descriptive documents with information about the sampling procedures, analytical methods, quality control and quality assurance procedures, description of the sampling stations and monitoring problems encountered.

About $50 \%$ of the data was collected in the Chesapeake Bay region (EPA rain zone 2). Other geographical regions with large number of observations in the NSQD database included EPA rain zones 5 and 6 (Texas and Southwest respectively) with approximately $10 \%$ of the total observations each. Figure 20.1 shows the location of the municipalities included in this database by EPA rain zones. The results from this project can be

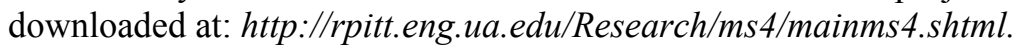




\subsubsection{The International BMP Database (BMP Database)}

The International BMP database is a compilation of data obtained from many projects that evaluate the performance of structural and non structural stormwater controls. Only the influent (untreated) concentrations were used in the analyses described in this chapter. A total of 132 sites in 71 communities were included in the database. A total of 3,800 storm events and 236 constituents were identified.

All the standard pollutants described in the NURP database were also included in the BMP database. The BMP database also included a large number of observations for total dissolved solids (TDS), total nitrogen (TN), total nitrate $\left(\mathrm{TNO}_{3}\right)$, total cadmium $(\mathrm{Cd})$, ammonia $\left(\mathrm{NH}_{3}\right), \mathrm{pH}$, hardness, total organic carbon (TOC), iron (Fe), and oil and grease (O\&G) amongst other constituents.

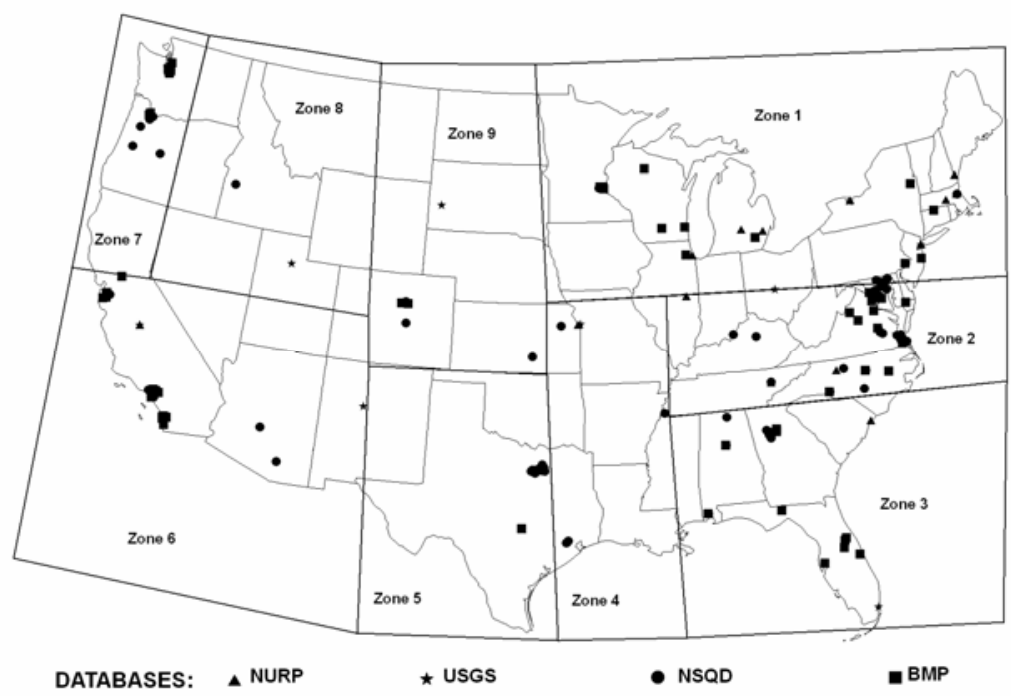

Figure 20.1 Locations included in the analysis by EPA rain zones.

The supportive information describing the sampling locations and event characteristics is very complete in this database. The database included rainfall - runoff information, including peak 1-h precipitation rates, peak flow rates, and total flow volumes. The description of the drainage areas included total impervious area, percentage of impervious area that is hydraulic connected, slope, and soil information. 
The BMP database has the best balanced geographical distribution of data of the four examined. All the rain zones are presented ( $9 \%$ to $22 \%$ for most EPA rain zones), except for the lower Mississippi valley (zone 4), California (zone 8), and the Rocky Mountains (zone 9). Figure 20.1 shows the location of the municipalities included in this database by rain zones

\subsection{Methods}

Data from the four databases were assembled into a single spreadsheet. Each dataset was analyzed individually. Data from the NURP reports was complemented and compared with the quality control reports created by the University of Illinois. The USGS monitored several of the NURP program sites and these sites are therefore duplicated in both databases. When the NURP and USGS databases reported the same storm event, both records were compared and complemented. The most complete data set was retained for each duplicated event (usually from the USGS database as additional detailed precipitation and runoff data was available). The NSQD, version 2 beta is available at: http://rpitt.eng.ua.edu/Research/ms4/mainms4.shtml.

Table 20.1 Main land uses, EPA rain zones and seasons identified in the assembled database.

\begin{tabular}{lll}
\hline \multicolumn{1}{c}{ LAND USE } & \multicolumn{1}{c}{ EPA RAIN ZONE } & \multicolumn{1}{c}{ SEASON } \\
\hline Agricultural & Zone 1 - Great Lakes & Spring: February - April \\
Commercial & Zone 2 - Northeast & Summer: May - July \\
Forested & Zone 3 - Southeast & Fall: August - October \\
Freeway & Zone 4 - Lower Mississippi Valley & Winter: November - January \\
Industrial & Zone 5 - Texas & \\
Institutional & Zone 6 - Southwest & \\
Open Space & Zone 7 - Northwest & \\
Residential & Zone 8 - California & \\
Mixed Agricultural & Zone 9- Rocky Mountain & \\
Mixed Commercial & & \\
Mixed Forested & & \\
Mixed Freeway & & \\
Mixed Industrial & & \\
Mixed Institutional & & \\
Mixed Open Space & & \\
Mixed Residential & & \\
\hline
\end{tabular}

More than 10,000 events were collected for the complete database. Table 20.1 shows the 16 land uses, 9 EPA rain zones and four seasons 
identified in the assembled database. The land uses were assigned categories according to their predominant land use in the watershed. When more than one predominated it was deemed a mixed site with the major land use noted.

About $30 \%$ of the total storm events stored in the assembled database were collected in residential land use areas, followed by mixed residential and commercial areas with $16 \%$ and $15 \%$ respectively. The land uses with the fewest events in the database were mixed freeways, mixed agricultural and mixed institutional areas with under $0.3 \%$ of the total number of events.

A total of 594 sampling locations are included in the assembled database. Most were located in EPA rain zone $2(37 \%)$ followed by EPA rain zone 6 (11\%). EPA rain zone 8 had the fewest sites, with only $2 \%$ of the total.

The data was also labeled according to the season when it was collected. The four seasons were identified according to their similar temperature patterns. As an example, Maestre (2005) found that the temperature of the stormwater samples during the period February - July was higher than for samples collected during the other six months of the year.

When analyzing the factors that affect stormwater, it is important to remember that the EPA rain zone and land use categories are different for each site group, while the season changed for each site. The distribution of samples collected during seasons varied from database to database. In the BMP and NSQD databases most of the samples were collected in the spring, while in the NURP and USGS databases they were collected during summer and fall. None of the databases included significant snowmelt information Table 20.2 shows the distribution of events by season in each database.

Table 20.2 Storm events distribution by season and database.

\begin{tabular}{lrrrrr}
\hline \multicolumn{1}{c}{ DATABASE } & \multicolumn{1}{c}{ SPRING } & SUMMER & \multicolumn{1}{c}{ FALL } & WINTER & TOTAL \\
\hline NURP & 407 & 618 & 613 & 220 & 1,858 \\
USGS & 189 & 441 & 287 & 104 & 1,021 \\
NSQD & 1,103 & 694 & 847 & 1,049 & 3,693 \\
BMP & 1,014 & 906 & 847 & 665 & 3,432 \\
Assembled & 2,713 & 2,659 & 2,594 & 2,038 & 10,004 \\
\hline
\end{tabular}

Land use and EPA rain zone representative data also varied among the databases. For example, there were no samples collected in EPA rain zone 8 during the NURP program. In order to compare data for each rain zone and land use, sufficient data observations are needed in each category to represent the range of conditions likely to occur. Table 20.3 shows the total number of events by database, EPA rain zone and land use. 
Table 20.3 Number of storm events land use and EPA rain zone: (a) NURP, (b) USGS, (c) NSQD, (d) BMP, (e) Assembled Database.

\begin{tabular}{|c|c|c|c|c|c|c|c|c|c|c|}
\hline LAND USE / NURP & 1 & 2 & 3 & 4 & 5 & 6 & 7 & 8 & 9 & ALL \\
\hline Commercial & 131 & 77 & 12 & 24 & & & & & & 244 \\
\hline Industrial & 23 & & & & & & & & & 23 \\
\hline Residential & 137 & 351 & 12 & 29 & 24 & & 119 & & & 672 \\
\hline Mixed Agricultural & 1 & & & & & & & & & 1 \\
\hline Mixed Commercial & 84 & 67 & & 16 & & & & & & 167 \\
\hline Mixed Forested & 126 & & & & & & & & & 126 \\
\hline Mixed Industrial & & & & 20 & & & & & & 20 \\
\hline Mixed Institutional & & & 27 & & & & & & & 27 \\
\hline Mixed Residential & 135 & 260 & 15 & & & 26 & 127 & & 15 & 578 \\
\hline ALL & 637 & 755 & 66 & 89 & 24 & 26 & 246 & & 15 & 1,858 \\
\hline
\end{tabular}

(a)

\begin{tabular}{|c|c|c|c|c|c|c|c|c|c|c|}
\hline LAND USE / USGS & 1 & 2 & 3 & 4 & 5 & 6 & 7 & 8 & 9 & ALL \\
\hline Commercial & 35 & & 31 & 3 & & 29 & & & 30 & 128 \\
\hline Forested & & & & & & & & & 7 & 7 \\
\hline Open Space & & & & & 1 & & & & & 1 \\
\hline Residential & 96 & 11 & 33 & & 4 & 19 & 38 & & 38 & 239 \\
\hline Mixed Agricultural & 14 & & & 12 & & & & & & 26 \\
\hline Mixed Commercial & 64 & & & & & & & 17 & 5 & 86 \\
\hline Mixed Forested & 17 & & & & & & 14 & & 24 & 55 \\
\hline Mixed Freeway & & & & & & & 10 & & & 10 \\
\hline Mixed Industrial & & & & & & 18 & & & & 18 \\
\hline Mixed Open Space & & & 42 & & & & & & 41 & 83 \\
\hline Mixed Residential & 165 & 10 & 9 & & 10 & 15 & 62 & 56 & 41 & 368 \\
\hline ALL & 391 & 21 & 115 & 15 & 15 & 81 & 124 & 73 & 186 & 1,021 \\
\hline
\end{tabular}

(b)

\begin{tabular}{|c|c|c|c|c|c|c|c|c|c|c|}
\hline LAND USE / NSQD & 1 & 2 & 3 & 4 & 5 & 6 & 7 & 8 & 9 & ALL \\
\hline Commercial & 3 & 307 & 24 & 41 & 41 & 37 & 42 & & 25 & 520 \\
\hline Freeway & & 2 & & & & 154 & 26 & & & 183 \\
\hline Industrial & 13 & 250 & 69 & 50 & 46 & 74 & 25 & & 19 & 546 \\
\hline Institutional & & 18 & & & & & & & & 18 \\
\hline Open Space & 1 & 26 & & 18 & & 2 & & & & 47 \\
\hline Residential & 25 & 672 & 58 & 75 & 71 & 45 & 52 & 7 & 23 & 1,028 \\
\hline Mixed Commercial & & 188 & 5 & 4 & 66 & 5 & 30 & 8 & 7 & 313 \\
\hline Mixed Freeway & 3 & 8 & & & 13 & & & & & 24 \\
\hline Mixed Industrial & & 107 & 23 & & 65 & 27 & 6 & & 20 & 248 \\
\hline Mixed Open Space & & 82 & & & 73 & & & & 7 & 162 \\
\hline Mixed Residential & 24 & 314 & 85 & 22 & 98 & 11 & 18 & 9 & 23 & 604 \\
\hline ALL & 69 & 1975 & 264 & 210 & 473 & 355 & 199 & 24 & 124 & 3,693 \\
\hline
\end{tabular}

(c) 
Table 20.3 (continued). Number of storm events land use and EPA rain zone: (d) BMP, (e) Assembled Database.

\begin{tabular}{|c|c|c|c|c|c|c|c|c|c|c|}
\hline LAND USE /BMP & 1 & 2 & 3 & 4 & 5 & 6 & 7 & 8 & 9 & ALL \\
\hline Agricultural & & & 91 & & & & & & & 91 \\
\hline Commercial & & 142 & 423 & & & 6 & 12 & & & 583 \\
\hline Forested & & 32 & & & & & & & & 32 \\
\hline Freeway & & 196 & & & 262 & 180 & & & & 648 \\
\hline Industrial & 67 & 24 & 12 & & & 87 & 136 & & 54 & 380 \\
\hline Institutional & 53 & 160 & 73 & & & 10 & & & & 296 \\
\hline Open Space & & 52 & & & & 157 & 8 & & & 217 \\
\hline Residential & 305 & 189 & 156 & & 28 & & 288 & & 116 & 1,082 \\
\hline Mixed Agricultural & 5 & & & & & & & & & 5 \\
\hline Mixed Commercial & & & & & 9 & & & & & 9 \\
\hline Mixed Open Space & 33 & & & & & & & & & 33 \\
\hline Mixed Residential & & & 33 & & & & 23 & & & 56 \\
\hline ALL & 463 & 795 & 788 & & 299 & 440 & 477 & & 170 & 3,432 \\
\hline
\end{tabular}

(d)

\begin{tabular}{|c|c|c|c|c|c|c|c|c|c|c|}
\hline LAND USE /ALL & 1 & 2 & 3 & 4 & 5 & 6 & 7 & 8 & 9 & ALL \\
\hline Agricultural & & & 91 & & & & & & & 91 \\
\hline Commercial & 169 & 526 & 490 & 68 & 41 & 72 & 54 & & 55 & 1,475 \\
\hline Forested & & 32 & & & & & & & 7 & 39 \\
\hline Freeway & & 199 & & & 262 & 334 & 36 & & & 831 \\
\hline Industrial & 103 & 274 & 81 & 50 & 46 & 161 & 161 & & 73 & 949 \\
\hline Institutional & 53 & 178 & 73 & & & 10 & & & & 314 \\
\hline Open Space & 1 & 78 & & 18 & 1 & 159 & 8 & & & 265 \\
\hline Residential & 563 & 1,223 & 259 & 104 & 127 & 64 & 497 & 7 & 177 & 3,021 \\
\hline Mixed Agricultural & 20 & & & 12 & & & & & & 32 \\
\hline Mixed Commercial & 148 & 255 & 5 & 20 & 75 & 5 & 30 & 25 & 12 & 575 \\
\hline Mixed Forested & 143 & & & & & & 14 & & 24 & 181 \\
\hline Mixed Freeway & 3 & 8 & & & 13 & & 10 & & & 34 \\
\hline Mixed Industrial & & 107 & 23 & 20 & 65 & 45 & 6 & & 20 & 286 \\
\hline Mixed Institutional & & & 27 & & & & & & & 27 \\
\hline Mixed Open Space & 33 & 82 & 42 & & 73 & & & & 48 & 278 \\
\hline Mixed Residential & 324 & 584 & 142 & 22 & 108 & 52 & 230 & 65 & 79 & 1,606 \\
\hline ALL & 1,560 & 3,546 & 1,233 & 314 & 811 & 902 & 1,046 & 97 & 495 & 10,004 \\
\hline
\end{tabular}

(e)

As noted earlier most of the data from the NURP program was collected in EPA rain zones 1 and 2 for residential, mixed residential and commercial land uses. Most of the USGS information was collected in the same land uses selected by the NURP program but in EPA rain zones 1 and 9. The BMP database has a good representation of residential, industrial, institutional and freeway land uses in all EPA rain zones except for EPA rain zones 4 and 8 . The NSQD database has the best representation of land uses 
and EPA rain zones among the four databases. All the EPA rain zones were well represented in the NSQD database except for EPA rain zones 1 and 8.

Merging the four databases filled-in some of the missing land uses and rain zone categories that the individual databases missed. Table 20.3 (e) shows the total number of storm events by land use and EPA rain zone in the assembled database. All of the EPA rain zones, except EPA rain zone 8 have enough events to be included in the full analyses. The following land uses can also be included in the full analyses: commercial, freeway, industrial, residential, mixed commercial, mixed industrial and mixed residential. Open space and mixed open space can be combined, but there were significantly differences in TSS and $\mathrm{Zn}$ concentrations between these two related subgroups, with a level of significance of $5 \%$.

Non-detected information in the NSQD database was estimated using the maximum likelihood method, in the remaining databases censored information was replaced by replacing the censored data with half the detection limit. Maestre (2005) found that replacing the censored observations by half the detection limit when the percentage of censored observations is smaller than $15 \%$ does not result in a significant change in the estimated median and standard deviation values for the dataset values.

Only Event Mean Concentrations (EMCs) of nine stormwater constituents were included in the assembled database: total suspended solids (TSS), 5-day biochemical oxygen demand $\left(\mathrm{BOD}_{5}\right)$, chemical oxygen demand (COD), total phosphorus (TP), Total Kjeldahl Nitrogen (TKN), nitrite plus nitrate $\left(\mathrm{NO}_{2}+\mathrm{NO}_{3}\right)$, total copper $(\mathrm{Cu})$, total lead $(\mathrm{Pb})$, and total zinc $(\mathrm{Zn})$. The selection of these constituents was determined based on their inclusion in the NURP program. Care must also be taken because some of the data were collected over a 25 y time period, and. As will be shown later significant lead concentrations variations occurred over this period. Also, the sampling location (inlet vs. outlet location) can have a significant effect on the observed concentrations, especially for TSS. Inlet samples usually have larger concentrations compared to outfall samples due to particulate solids deposition in the sewerage.

\subsection{Analyses and Results}

The following three questions were addressed using the assembled database:

- Are individual site differences more significant than the type of land use? 
- Are there any significant differences in the EMC concentrations of stormwater constituents by season?

- Is there any significant difference in the EMC concentration by land use and/or EPA rain zone?

\subsubsection{Individual differences vs. land use}

Only data from EPA rain zone 2 was selected for these analyses, as the other zones lack sufficient detailed information. EPA rain zone 2 has the largest number of observations in the database, and all land uses were represented, except for agricultural, mixed agricultural, mixed forested, mixed freeway, and mixed institutional. The Xbar-S control chart was selected to evaluate differences among land uses. EPA (1983) found that stormwater constituents are $\log$ normally distributed. Maestre et al. (2005) also evaluated the probability distributions of the stormwater quality data in the NSQD database and confirmed that log-normal distributions are very common for the constituents included in that stormwater database, with few exceptions (such as for $\mathrm{pH}$ ). Observations from the combined database were therefore $\log$ transformed in order to use the control charts.

\section{Xbar-S Chart of TSS $\mathrm{mg} / \mathrm{L}$ in EPA rain zone 2}
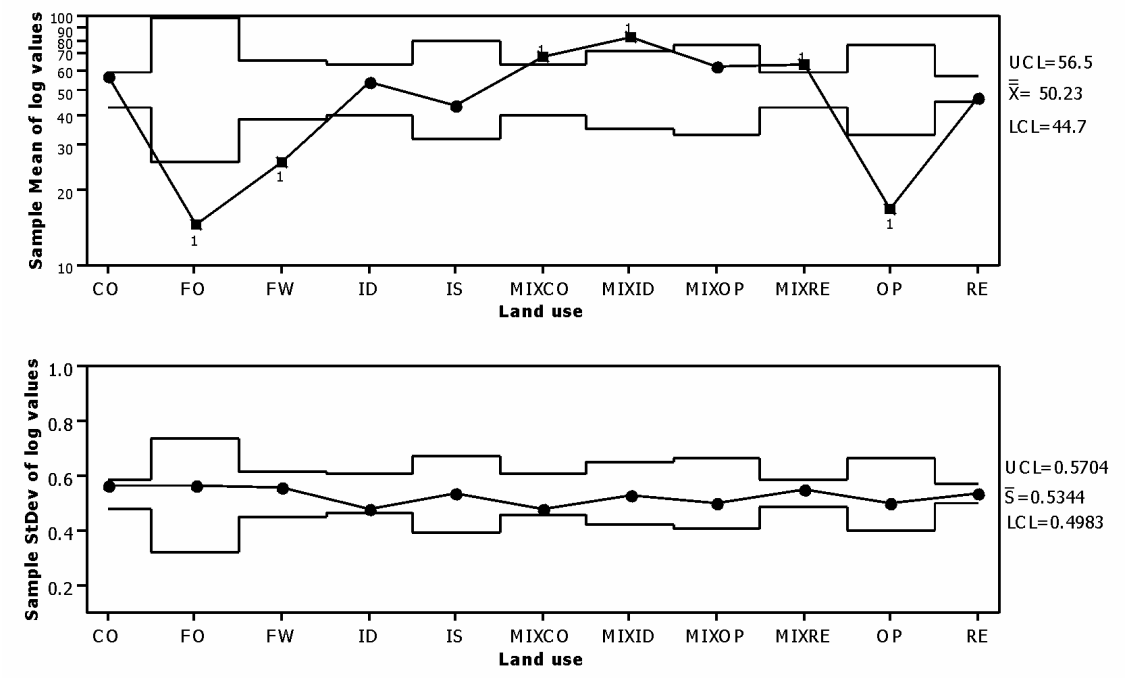

Figure 20.2 Xbar-S chart EPA rain zones. 
The Xbar-S control chart is useful to identify differences among groups of data. One of the main advantages is that the chart adjusts the control limits according to the number of observations at each site. If a site has a median value significantly different from the others sites in the same group, it will appear outside the control limits. For example, Figure 20.2 shows how the TSS concentrations change among the different land use categories in EPA rain zone 2.

For TSS in EPA rain zone 2, five land uses are found to be outside the control limits for the median TSS concentration. Samples collected in open space, forested and freeways land uses are shown to have lower TSS concentrations when compared with the remaining land uses. However, some of the mixed land uses have a higher concentration than other categories designated with a single land use. All the land uses have a similar standard deviation; none of the land uses had a standard deviation outside the control limits. The values in the $\mathrm{S}$ chart correspond to the standard deviation of the $\log$ transformed observations. The range of the control limits is a function of the number of observations in each land use category. The residential land use category has the smallest control limit range because it has the largest number of data observations, while the forested category has the largest control limit range because it has the smallest number of data observations.

Table 20.4 lists the land uses categories outside the control limits for the nine constituents examined. If the land use was above the upper control limit, it is represented with the letter $\mathrm{H}$, and if below it is represented with an L. Open space and mixed open space show the lowest stormwater concentrations among all land uses and constituents, as would be expected. Unfortunately only TSS and TP concentrations were obtained from the forested sites, so the other constituents cannot be compared for this category. TSS median concentrations from forested sites were the lowest among all land uses. In contrast, commercial and mixed residential land uses showed large copper, lead and zinc concentrations. Freeways sites also had elevated concentrations of total phosphorus and nitrates.

The variability of the concentrations also depends on the land use and stormwater constituent. For example a lower variability was identified for the COD concentrations compared to the copper concentrations for freeways. In the open space category, a larger variability was identified for total phosphorus, total nitrite plus nitrate, and zinc, than for other categories. A modified Xbar-S chart was also used to evaluate the variability within the same land use. Figure 20.3 is an example showing the variability among all sites in the residential land use category for the EPA rain zone 2. 
Table 20.4 Land uses outside the control limits by constituent.

\begin{tabular}{|c|c|c|c|c|c|c|c|c|c|c|c|c|c|c|c|c|c|c|}
\hline LAND USE & TS & & $\mathrm{BO}$ & & $\mathrm{CO}$ & & $\mathrm{Tl}$ & & $\begin{array}{l}\mathrm{NO} \\
\mathrm{NC}\end{array}$ & & $\mathrm{TK}$ & & & & & & & \\
\hline & $\mu$ & $\sigma$ & $\mu$ & $\sigma$ & $\mu$ & $\sigma$ & $\mu$ & $\sigma$ & $\mu$ & $\sigma$ & $\mu$ & $\sigma$ & $\mu$ & $\sigma$ & $\mu$ & $\sigma$ & $\mu$ & $\sigma$ \\
\hline Commercial & & & $\mathrm{H}$ & & & & $\mathrm{L}$ & & & $\mathrm{L}$ & & & $\mathrm{H}$ & & $\mathrm{H}$ & & $\mathrm{H}$ & $\mathrm{L}$ \\
\hline Forested & $\mathrm{L}$ & & - & - & - & - & & & - & - & - & - & - & - & - & - & - & - \\
\hline Freeway & $\mathrm{L}$ & & - & - & & $\mathrm{L}$ & $\mathrm{H}$ & & $\mathrm{H}$ & & - & - & $\mathrm{L}$ & $\mathrm{H}$ & & & & \\
\hline Industrial & & & & & & & $\mathrm{L}$ & & & & $\mathrm{L}$ & & $\mathrm{L}$ & & $\mathrm{L}$ & $\mathrm{L}$ & $\mathrm{H}$ & \\
\hline Institutional & & & & & & & $\mathrm{L}$ & $\mathrm{H}$ & $\mathrm{L}$ & & $\mathrm{H}$ & & $\mathrm{L}$ & & $\mathrm{L}$ & & & \\
\hline Open Space & $\mathrm{L}$ & & $\mathrm{L}$ & & $\mathrm{L}$ & & $\mathrm{L}$ & $\mathrm{H}$ & $\mathrm{L}$ & $\mathrm{H}$ & $\mathrm{L}$ & & $\mathrm{L}$ & & $\mathrm{L}$ & & & $\mathrm{H}$ \\
\hline Residential & & & & & & $\mathrm{L}$ & $\mathrm{H}$ & $\mathrm{L}$ & & & & & & & & $\mathrm{H}$ & $\mathrm{L}$ & \\
\hline $\begin{array}{l}\text { Mixed } \\
\text { Commercial }\end{array}$ & $\mathrm{H}$ & & & & $\mathrm{H}$ & $\mathrm{H}$ & & & & L & & & $\mathrm{H}$ & & & & & \\
\hline $\begin{array}{l}\text { Mixed } \\
\text { Industrial }\end{array}$ & $\mathrm{H}$ & & & & $\mathrm{L}$ & & & & & $\mathrm{L}$ & & $\mathrm{H}$ & & & $\mathrm{L}$ & $\mathrm{L}$ & & \\
\hline $\begin{array}{l}\text { Mixed Open } \\
\text { Space }\end{array}$ & & & $\mathrm{L}$ & & $\mathrm{L}$ & & & & & & $\mathrm{L}$ & & $\mathrm{L}$ & & $\mathrm{L}$ & $\mathrm{L}$ & & \\
\hline $\begin{array}{l}\text { Mixed } \\
\text { Residential }\end{array}$ & $\mathrm{H}$ & & $\mathrm{L}$ & & & & & & & & $\mathrm{H}$ & & $\mathrm{H}$ & $\mathrm{H}$ & $\mathrm{H}$ & & $\mathrm{L}$ & \\
\hline
\end{tabular}

TSS mg/L by Site in Residential Land Use and EPA Rain Zone 2

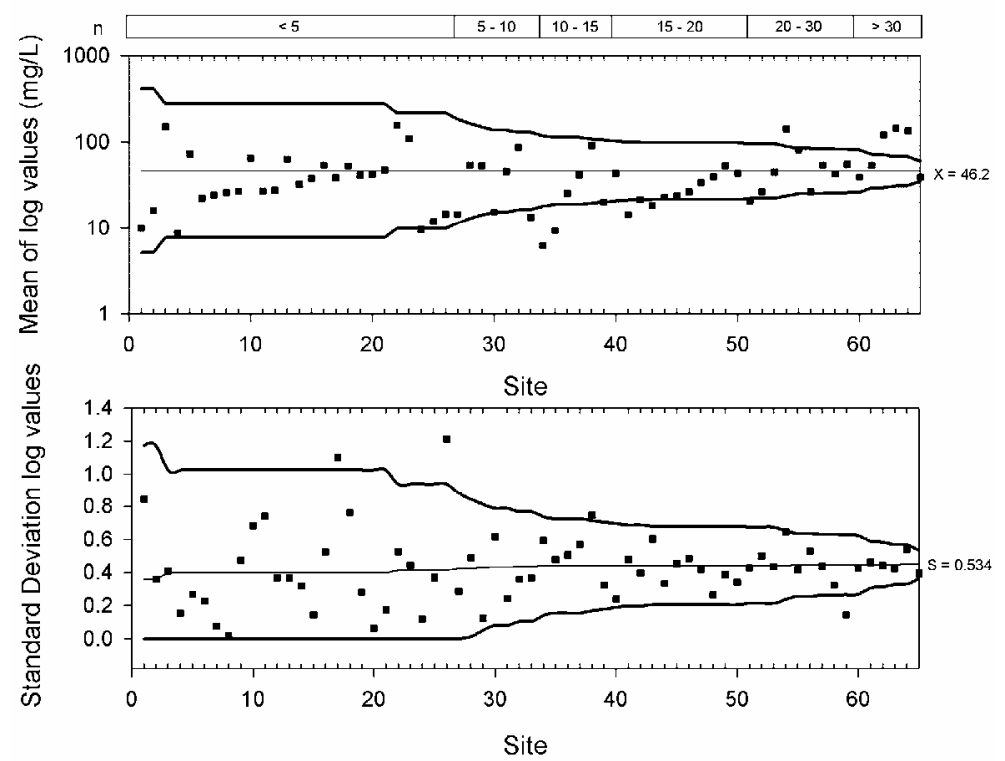

Figure 20.3 Modified Xbar-S chart for residential TSS in rain zone 2. 
About $18 \%$ of the 65 residential sites with TSS concentrations in EPA rain zone 2 were outside the control limits, indicating that there are specific variations between sites in the same land use. The critical cases are those where the distance between control limits is small. For example, sites 60 to 65 in Figure 20.3 have enough samples to show that the TSS concentration in site 63 is almost 3 times the concentration of site 65 . The $S$ chart indicates that $6 \%$ of the sites have a standard deviation different from the remaining residential sites in EPA rain zone 2. The variation in the standard deviation between sites is not as large as the variation in the median concentrations.

Table 20.5 shows that in almost all cases, except for open space and forest categories, the pooled standard deviation among land uses was in general larger than the standard deviation within sites for the same land use. The number of samples in these two land uses was small compared with the number of samples in the other land uses.

To determine if there is a difference between the standard deviation between and within the land uses, a normal probability plot of the standard deviations was created. If all the standard deviations follow the same distribution, they will appear as a straight line in the probability plot. Land uses significantly different will be outside the line. Figure 20.4 shows the probability plots of standard deviations by constituent.

Table 20.5 Pooled standard deviation of log concentrations by constituent.

\begin{tabular}{|c|c|c|c|c|c|c|c|c|c|}
\hline $\begin{array}{l}\text { Standard } \\
\text { deviation within } \\
\text { land uses }\end{array}$ & TSS & BOD & COD & $\mathrm{TP}$ & $\begin{array}{c}\mathrm{NO} 2 \\
+ \\
\mathrm{NO} 3\end{array}$ & TKN & $\mathrm{Cu}$ & $\mathrm{Pb}$ & $\mathrm{Zn}$ \\
\hline $\begin{array}{l}\text { Between Land } \\
\text { Uses }\end{array}$ & 0.534 & 0.382 & 0.377 & 0.391 & 0.431 & 0.357 & 0.445 & 0.778 & 0.462 \\
\hline Commercial & 0.450 & 0.306 & 0.341 & 0.278 & 0.346 & 0.314 & 0.260 & 0.340 & 0.264 \\
\hline Forest & 0.567 & & & 0.524 & & & & & \\
\hline Freeways & 0.372 & & 0.263 & 0.356 & 0.630 & & 0.392 & 0.224 & 0.355 \\
\hline Industrial & 0.427 & 0.350 & 0.312 & 0.325 & 0.305 & 0.378 & 0.293 & 0.455 & 0.268 \\
\hline Institutional & 0.405 & 0.386 & 0.367 & 0.362 & 0.401 & 0.301 & 0.290 & 0.372 & 0.337 \\
\hline Open Space & 0.418 & 0.313 & 0.281 & 0.540 & 0.310 & 0.179 & 0.273 & 0.695 & 0.424 \\
\hline Residential & 0.443 & 0.329 & 0.282 & 0.298 & 0.327 & 0.286 & 0.315 & 0.389 & 0.343 \\
\hline $\begin{array}{l}\text { Mixed } \\
\text { commercial }\end{array}$ & 0.342 & 0.282 & 0.331 & 0.359 & 0.290 & 0.280 & 0.304 & 0.460 & 0.470 \\
\hline Mixed industrial & 0.493 & 0.304 & 0.357 & 0.373 & 0.243 & 0.395 & 0.218 & 0.438 & 0.352 \\
\hline $\begin{array}{l}\text { Mixed open } \\
\text { space }\end{array}$ & 0.420 & 0.400 & 0.420 & 0.376 & 0.307 & 0.318 & 0.220 & 0.472 & 0.365 \\
\hline $\begin{array}{l}\text { Mixed } \\
\text { Residential }\end{array}$ & 0.476 & 0.290 & 0.287 & 0.320 & 0.341 & 0.265 & 0.295 & 0.434 & 0.390 \\
\hline
\end{tabular}




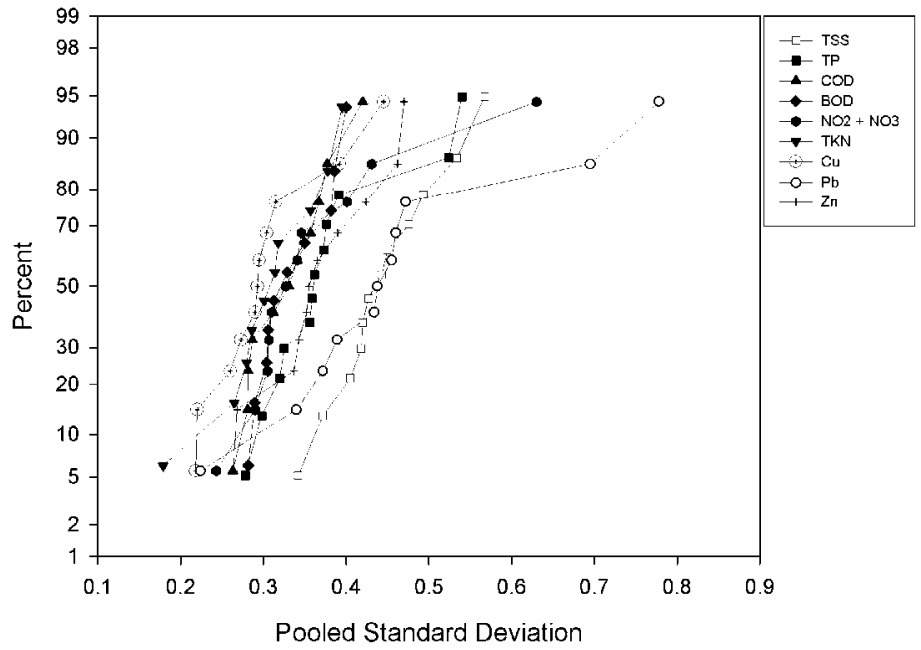

Figure 20.4 Probability plot of pooled standard deviation in EPA rain zone 2.

TSS and total lead were the constituents with the highest standard deviations, while total copper had the lowest. Four constituents did not follow a straight line. The worst case was lead. Lead has been banned from gasoline since 1986. Because the assembled database contains data from the late $1970 \mathrm{~s}$, it is possible to find elevated lead concentrations in the database. Figure 20.5 shows the change in lead among all land uses in EPA rain zone 2 from 1978 to 2002. Although the range of lead concentrations for any narrow range of years is quite large, there is a significant and obvious trend in concentration for the 20 years between 1980 to 2000 .

The other three constituents that did not follow a normal distribution were total nitrite plus nitrate, total phosphorus and total copper. Total nitrite and nitrate and copper in freeways have a larger standard deviation when compared with the remaining land uses. Fraser, et al. (1998) found that ammonia emissions have increased since the use of three way catalytic converters. The reaction between ammonia and nitric acid forms ammonium nitrate. Sutherland (2000) suggests that copper concentrations in runoff from highways originate from the wear of brake pads, tires, asphalt and concrete. Increases in traffic levels and higher average speeds results in higher copper concentrations. Finally expected variations in copper concentrations were also higher in forested and open space land uses, mostly because of the small number of samples obtained in these categories. 


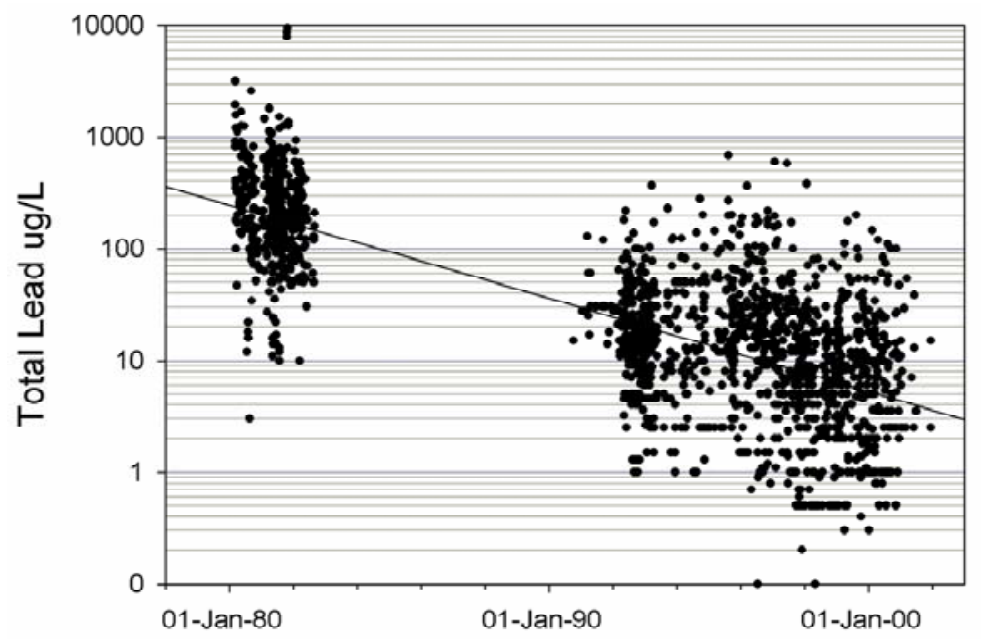

Figure 20.5 Total lead concentrations from EPA rain zone 2.

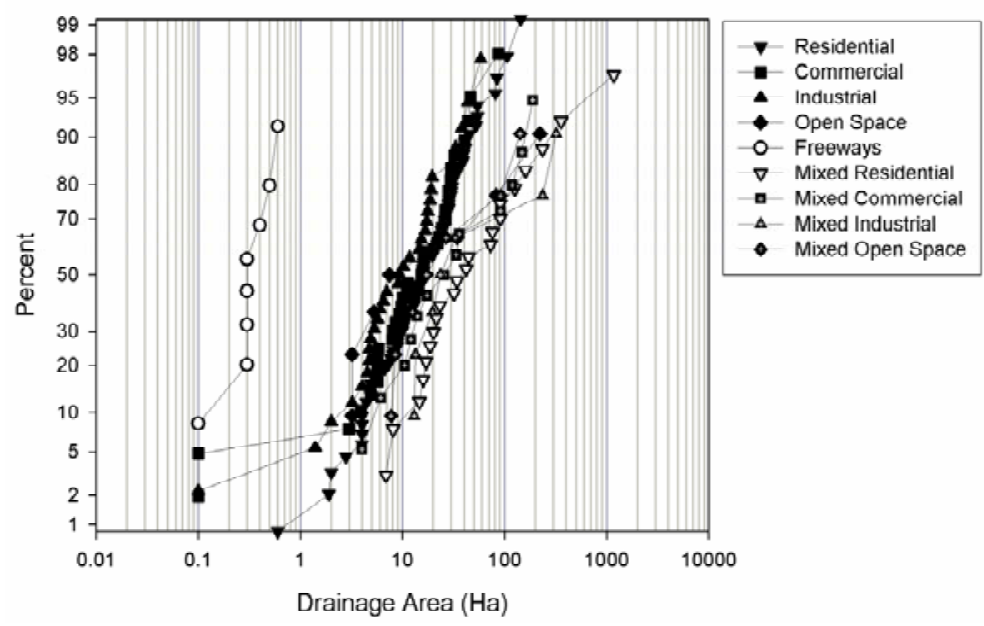

Figure 20.6 Probability plot of drainage area by land use in EPA rain zone 2 .

The size of the drainage area can also have an effect in the variability of the concentrations among land uses and sites. When the BMP database was analyzed alone, it was observed that the concentration of total dissolved 
solids, TKN, ammonia, COD, total nitrite plus nitrate, dissolved lead, dissolved zinc and oil and grease were higher in drainage areas smaller than 1 hectare compared to larger drainage areas. Figure 20.6 shows the probability plot of the drainage areas of each site in EPA rain zone 2.

Drainage areas at freeways sites were more than 10 times smaller than the other drainage areas. This may be one reason why freeways have elevated nutrients concentrations.

Another question of interest is what percentage of the sites will be outside the control limits for each category? This was determined using the number of sites out of the control limits in the X-bar S charts. Table 20.6 shows the total number of observations outside the upper and lower control limits. The table shows that $14 \%$ of the sites will have a median concentration smaller than the lower control limit in their land use. The largest percentage of sites below the lower control limit was observed in commercial and mixed residential land uses. The largest percentage of sites with median concentration smaller than the lower control limit was observed for lead (25\%) and copper (20\%).

Table 20.6 Sites outside control limits in the X-bar S chart.

\begin{tabular}{|c|c|c|c|c|c|c|c|c|c|c|c|c|c|c|c|c|}
\hline $\begin{array}{l}\text { LAND } \\
\text { USE }\end{array}$ & \multicolumn{4}{|c|}{ RESIDENTIAL } & \multicolumn{4}{|c|}{ COMMERCIAL } & \multicolumn{4}{|c|}{ INDUSTRIAL } & \multicolumn{4}{|c|}{$\begin{array}{c}\text { MIXED } \\
\text { RESIDENTIAL }\end{array}$} \\
\hline & \multicolumn{2}{|c|}{ Median } & \multicolumn{2}{|c|}{$\begin{array}{l}\text { Standard } \\
\text { Deviation }\end{array}$} & \multicolumn{2}{|c|}{ Median } & \multicolumn{2}{|c|}{$\begin{array}{l}\text { Standard } \\
\text { Deviation }\end{array}$} & \multicolumn{2}{|c|}{ Median } & \multicolumn{2}{|c|}{$\begin{array}{l}\text { Standard } \\
\text { Deviation }\end{array}$} & \multicolumn{2}{|c|}{ Median } & \multicolumn{2}{|c|}{$\begin{array}{r}\text { Standard } \\
\text { Deviation }\end{array}$} \\
\hline \multirow{3}{*}{ TSS mg/L } & H & $\mathbf{L}$ & $\mathrm{H}$ & $\mathbf{L}$ & H & $\mathbf{L}$ & $\mathrm{H}$ & $\mathbf{L}$ & H & $\mathbf{L}$ & $\mathrm{H}$ & $\mathbf{L}$ & H & $\mathbf{L}$ & H & $\mathbf{L}$ \\
\hline & \multicolumn{4}{|c|}{$\mathrm{n}=66$} & \multicolumn{4}{|c|}{$\mathrm{n}=32$} & \multicolumn{4}{|c|}{$\mathrm{n}=26$} & \multicolumn{4}{|c|}{$\mathrm{n}=24$} \\
\hline & 4 & 8 & 3 & 1 & 4 & 6 & 3 & 1 & 1 & 2 & 1 & 0 & 2 & 3 & 1 & 1 \\
\hline \multirow{2}{*}{ BOD mg/L } & \multicolumn{4}{|c|}{$\mathrm{n}=59$} & \multicolumn{4}{|c|}{$\mathrm{n}=27$} & \multicolumn{4}{|c|}{$\mathrm{n}=25$} & \multicolumn{4}{|c|}{$\mathrm{n}=20$} \\
\hline & 4 & 7 & 4 & 2 & 3 & 4 & 1 & 0 & 3 & 1 & 1 & 0 & 5 & 3 & 0 & 0 \\
\hline \multirow{2}{*}{ COD mg/L } & \multicolumn{4}{|c|}{$\mathrm{n}=49$} & \multicolumn{4}{|c|}{$\mathrm{n}=23$} & \multicolumn{4}{|c|}{$\mathrm{n}=16$} & \multicolumn{4}{|c|}{$\mathrm{n}=21$} \\
\hline & 7 & 6 & 5 & 2 & 2 & 5 & 1 & 1 & 1 & 1 & 2 & 0 & 4 & 3 & 1 & 2 \\
\hline \multirow{2}{*}{$\mathrm{TP} \mathrm{mg} / \mathrm{L}$} & \multicolumn{4}{|c|}{$\mathrm{n}=68$} & \multicolumn{4}{|c|}{$\mathrm{n}=29$} & & & & & & & & \\
\hline & 7 & 8 & 1 & 2 & 5 & 3 & 1 & 0 & 2 & 1 & 0 & 1 & 2 & 3 & 2 & 1 \\
\hline $\mathrm{NO} 2+$ & & & & & & & & & & & & & & & & \\
\hline $\mathrm{NO} 3 \mathrm{mg} / \mathrm{L}$ & 4 & 4 & 3 & 1 & 1 & 2 & 1 & 1 & 1 & 2 & 1 & 0 & 2 & 3 & 2 & 1 \\
\hline TKN mo/I & & & & & & & & & & & & & & & & \\
\hline $1 \mathrm{KN} \mathrm{mg} / \mathrm{L}$ & 8 & 4 & 4 & 3 & 2 & 1 & 2 & 0 & 2 & 1 & 3 & 0 & 4 & 4 & 0 & 1 \\
\hline & & & & & & & & & & & & & & & & \\
\hline $\mathrm{Cu} \mu \mathrm{g} / \mathrm{L}$ & 8 & 15 & 3 & 2 & 2 & 8 & 2 & 0 & 3 & 3 & 0 & 0 & 4 & 7 & 1 & 0 \\
\hline & & & & & & & & & & & & & & & & \\
\hline $\mathrm{Pb} \mu \mathrm{g} / \mathrm{L}$ & 9 & 21 & 3 & 1 & 3 & 12 & 3 & 1 & 1 & 1 & 1 & 0 & 4 & 9 & 2 & 1 \\
\hline & & & & & & & & & & & & & & & & \\
\hline $\mathrm{Zn} \mu \mathrm{g} / \mathrm{L}$ & 8 & 11 & 7 & 1 & 3 & 7 & 2 & 0 & 4 & 3 & 0 & 0 & 2 & 2 & 2 & 1 \\
\hline
\end{tabular}


Mixed land uses also showed the largest percentage of sites (14\%) with median concentrations greater than the upper control limit. The lowest percentage of sites $(7 \%)$ with concentrations larger than the upper control limit was observed for industrial land use sites. Industrial land use areas had the smallest variability in the standard deviation values. Less than $1 \%$ of the industrial sites had standard deviation values smaller than the lower control limit. Industrial land uses also have the smallest percentage of sites with standard deviations above the upper control limit. The largest variations occurred for the commercial land use category where almost $6 \%$ of the sites had standard deviations larger than the upper control limit in the S chart.

The smallest variations in the standard deviations were observed for copper and BOD, with less than $1 \%$ of the sites below the lower control limit and less than $4 \%$ with standard variation greater than the upper control limit in the $\mathrm{S}$ chart. The largest variation by constituent was observed for COD, where $8 \%$ of the sites showed a standard deviation greater than the upper control limit.

\subsubsection{Seasonal Analyses}

One Way Analysis of Variance (ANOVA) was selected to evaluate if there were significant seasonal differences in the EMC values of stormwater constituents by land use in EPA rain zone 2. The effects of the interactions of seasons with other factors are presented in the next section. The null hypothesis in this case was that there is no statistically significant difference in the EMC values amongst the seasons. The alternative is that there is a statistically significant difference. Table 20.7 shows the results from this ANOVA analysis ( $p$-values $<0.05$ usually indicates a significant difference, and these are high-lighted by italics in the table).

All the stormwater constituents showed seasonal differences in at least one land use. TSS showed significant seasonal differences except in forest, mixed open space, commercial and industrial land use categories. Open space, mixed commercial and mixed residential land use categories had TSS concentrations that were smaller during the winter than during the other seasons. Again, snowmelt data are not included in this database. At freeway locations the TSS concentrations in the fall were significantly greater than during the remaining seasons. Total phosphorus (TP) was another constituent that showed significant seasonal differences between land uses. Land uses with seasonal TP variability included freeways, industrial, institutional, residential, mixed commercial and mixed residential categories. In general, TP concentrations were higher during summer rains than for the 
other seasons. Also, the analysis showed a significant reduction in the TP concentration during the winter. The following constituents showed the lowest seasonal variability amongst land uses: $\mathrm{BOD}_{5}$, total nitrite plus nitrate, total copper and total lead.

Table $20.7 p$-values for seasonal analysis by land use in EPA rain zone 2.

\begin{tabular}{lccccccccc}
\hline \multicolumn{1}{c}{$\begin{array}{c}\text { Standard deviation } \\
\text { within land uses }\end{array}$} & TSS & BOD & COD & TP & $\begin{array}{c}\text { NO2 } \\
+ \\
\text { NO3 }\end{array}$ & TKN & Cu & Pb & Zn \\
\hline Commercial & 0.229 & 0.300 & 0.304 & 0.405 & 0.013 & 0.009 & 0.400 & 0.095 & 0.223 \\
Forest & 0.271 & & & 0.083 & & & & & \\
Freeways & 0 & & 0.766 & 0.012 & 0.003 & & 0.885 & 0.179 & 0.027 \\
Industrial & 0.346 & 0.449 & 0.047 & 0.022 & 0.015 & 0.364 & 0.882 & 0.626 & 0.618 \\
Institutional & 0.006 & 0.045 & 0.001 & 0.008 & 0.157 & 0.009 & 0.905 & 0.859 & 0.549 \\
Open Space & 0.045 & 0.129 & 0.633 & 0.839 & 0.964 & 0.387 & 0.851 & 0.786 & 0.024 \\
Residential & 0 & 0.055 & 0.001 & 0 & 0.378 & 0 & 0 & 0 & 0 \\
Mixed commercial & 0 & 0.143 & 0.010 & 0.024 & 0.677 & 0.047 & 0.018 & 0.002 & 0.510 \\
Mixed industrial & 0.056 & 0.112 & 0.322 & 0.535 & 0.547 & 0.341 & 0.086 & 0.095 & 0.796 \\
Mixed open space & 0.171 & 0.440 & 0.162 & 0.511 & 0.285 & 0.306 & 0.491 & 0.243 & 0.374 \\
Mixed Residential & 0 & 0.008 & 0 & 0.007 & 0.262 & 0.004 & 0.063 & 0.001 & 0.044 \\
\hline
\end{tabular}

Analyses by land use showed that mixed open space and mixed industrial land uses did not show any significant concentration differences by season for the nine stormwater constituents examined. However, all the constituents showed seasonal differences in the residential land use category except for total nitrate plus nitrite. Mixed residential and mixed commercial areas also showed significant differences by season for almost all the constituents. In open space areas, only TSS and total zinc showed a significant seasonal difference. In the commercial land use category, only total nitrate plus nitrite and TKN showed significant seasonal differences.

\subsubsection{Land Use and Geographical Region Analyses}

The final analyses used the general linear model (GLM) that also includes the interaction effects between land use, geographical region, and season. Section 20.3.2 showed that there are significant differences between seasons for several constituents and land uses in EPA rain zone 2, without considering the interactions. In this section, the effect of the interactions are evaluated, and for most of the regions of the country. It is important to have enough sample numbers representing each group to have sufficient statistical power during these analyses. Table 20.8 shows the main three factors and levels used in the GLM model 
Table 20.8 Main land uses, EPA rain zones and seasons identified.

\begin{tabular}{lll}
\hline \multicolumn{1}{c}{ LAND USE } & \multicolumn{1}{c}{ EPA RAIN ZONE } & \multicolumn{1}{c}{ SEASON } \\
\hline Commercial & Zone 1 - Great Lakes & Spring: February - April \\
Freeway & Zone 2 - Northeast & Summer: May - July \\
Industrial & Zone 3 - Southeast & Fall: August - October \\
Open Space & Zone 4 - Lower Mississippi Valley & Winter: November - January \\
Residential & Zone 5 - Texas & \\
& Zone 6 - Southwest & \\
& Zone 7 - Northwest & \\
& Zone 9 - Rocky Mountain & \\
\hline
\end{tabular}

Mixed land uses were excluded from these analyses to eliminate the confusing effects of different land uses in the same area. Rain zone 8 was also eliminated because none of the single land uses have observations in this EPA rain zone. All four seasons were selected as they were well represented in all the selected land uses and EPA rain zones.

Two-way and three-way interactions were included in the model. Table 20.9 shows the results from the model analyses. A p-value smaller than 0.05 indicates that the factor, or interaction of factors, was found to be significant at least at the $5 \%$ significance level.

Table 20.9 p-values for main factors and interactions.

\begin{tabular}{|c|c|c|c|c|c|c|c|}
\hline Constituent & $\begin{array}{l}\text { Land Use } \\
\quad(\mathrm{LU})\end{array}$ & $\begin{array}{l}\text { Season } \\
(\mathrm{SN})\end{array}$ & $\begin{array}{l}\text { EPA Rain } \\
\text { Zone } \\
\text { (EPA) }\end{array}$ & $\mathrm{LU}^{*} \mathrm{SN}$ & LU*EPA & SN*EPA & $\mathrm{LU}^{*} \mathrm{EPA}^{*} \mathrm{SN}$ \\
\hline TSS mg/L & $<0.0001$ & 0.737 & $<0.0001$ & 0.017 & $<0.0001$ & 0.1836 & $<0.0001$ \\
\hline BOD mg/L & $<0.0001$ & 0.1551 & $<0.0001$ & 0.0008 & $<0.0001$ & 0.0011 & 0.2209 \\
\hline $\mathrm{COD} \mathrm{mg} / \mathrm{L}$ & $<0.0001$ & 0.1341 & $<0.0001$ & 0.0343 & $<0.0001$ & 0.0137 & 0.0085 \\
\hline TP mg/L & $<0.0001$ & 0.6869 & $<0.0001$ & 0.0551 & $<0.0001$ & 0.0004 & $<0.0001$ \\
\hline $\begin{array}{l}\mathrm{NO} 2+\mathrm{NO} 3 \\
\mathrm{mg} / \mathrm{L}\end{array}$ & $<0.0001$ & 0.1075 & $<0.0001$ & 0.0524 & $<0.0001$ & 0.0343 & 0.057 \\
\hline TKN mg/L & 0.0026 & 0.0235 & $<0.0001$ & 0.9989 & $<0.0001$ & $<0.0001$ & 0.1671 \\
\hline $\mathrm{Cu} \mu \mathrm{g} / \mathrm{L}$ & $<0.0001$ & 0.1123 & $<0.0001$ & 0.6226 & $<0.0001$ & 0.0382 & 0.1405 \\
\hline $\mathrm{Pb} \mu \mathrm{g} / \mathrm{L}$ & $<0.0001$ & 0.7645 & $<0.0001$ & 0.4203 & $<0.0001$ & 0.2854 & 0.0117 \\
\hline $\mathrm{Zn} \mu \mathrm{g} / \mathrm{L}$ & $<0.0001$ & 0.91 & $<0.0001$ & 0.9362 & $<0.0001$ & 0.0139 & $<0.0001$ \\
\hline
\end{tabular}

The results indicated that the factors for EPA rain zone, and land use, and the interaction land use-rain zone were the most important factors used in the model. There were significant differences by EPA rain zone, and land use for all the constituents. The interaction of these two factors was also significant. Using the GLM and all the data, it was found that season alone 
was not significant for any constituent except for TKN. The interaction between land uses and EPA rain zone is very important and must be considered when determining likely stormwater concentrations for a site.
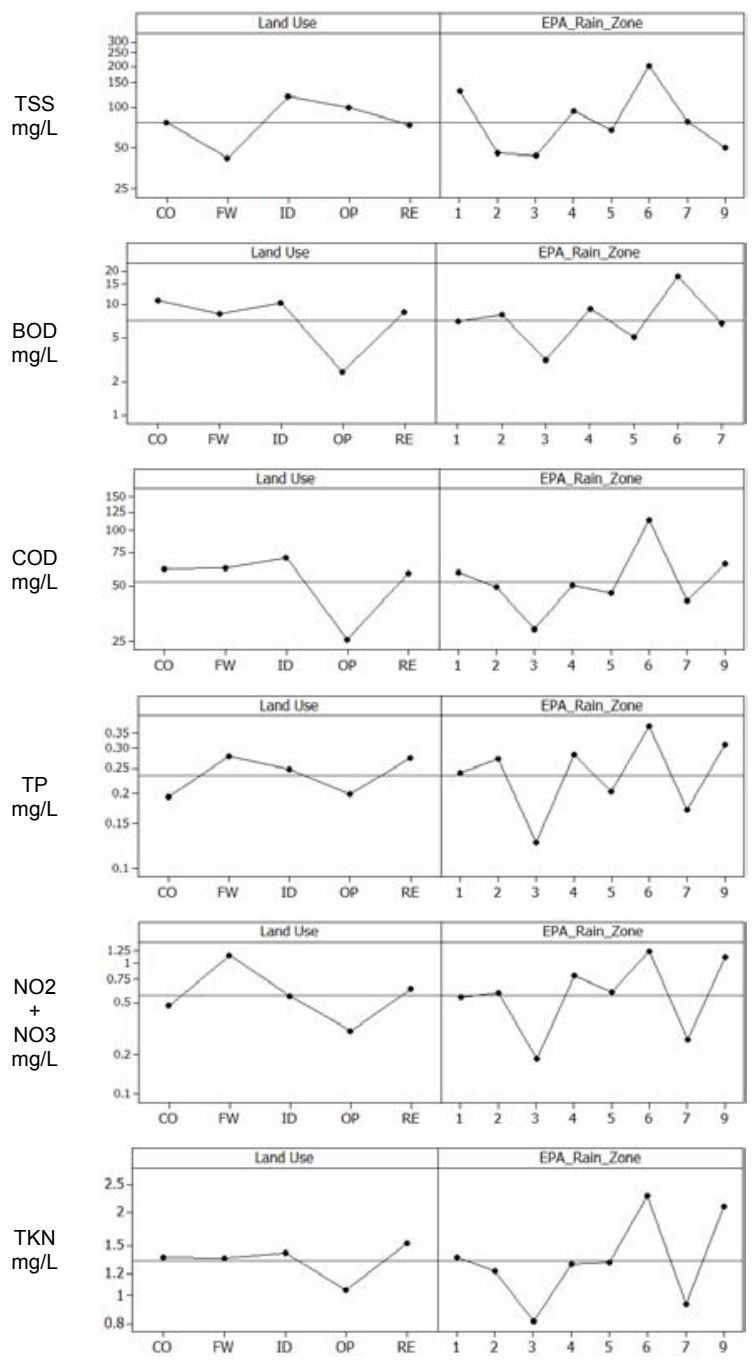

Figure 20. 7 Main factors plots for land use, EPA rain zone and season.
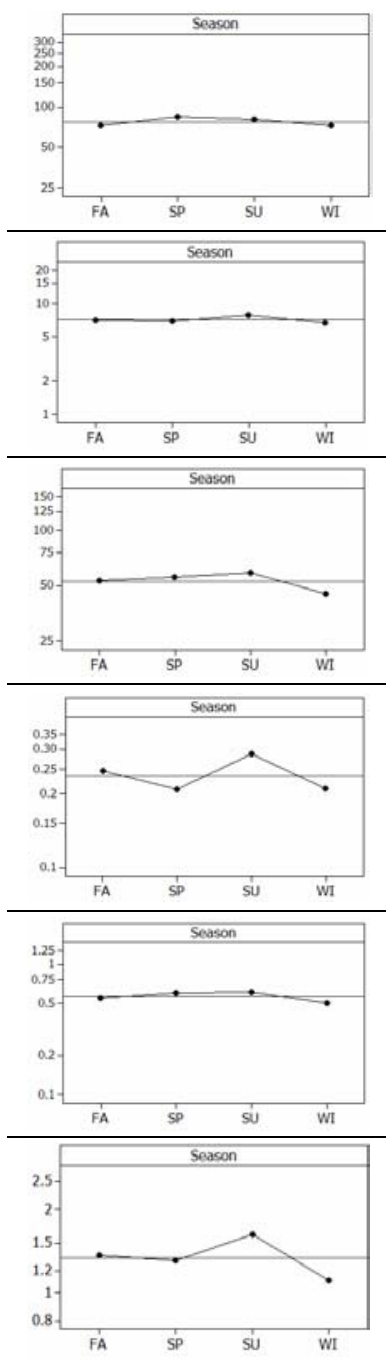

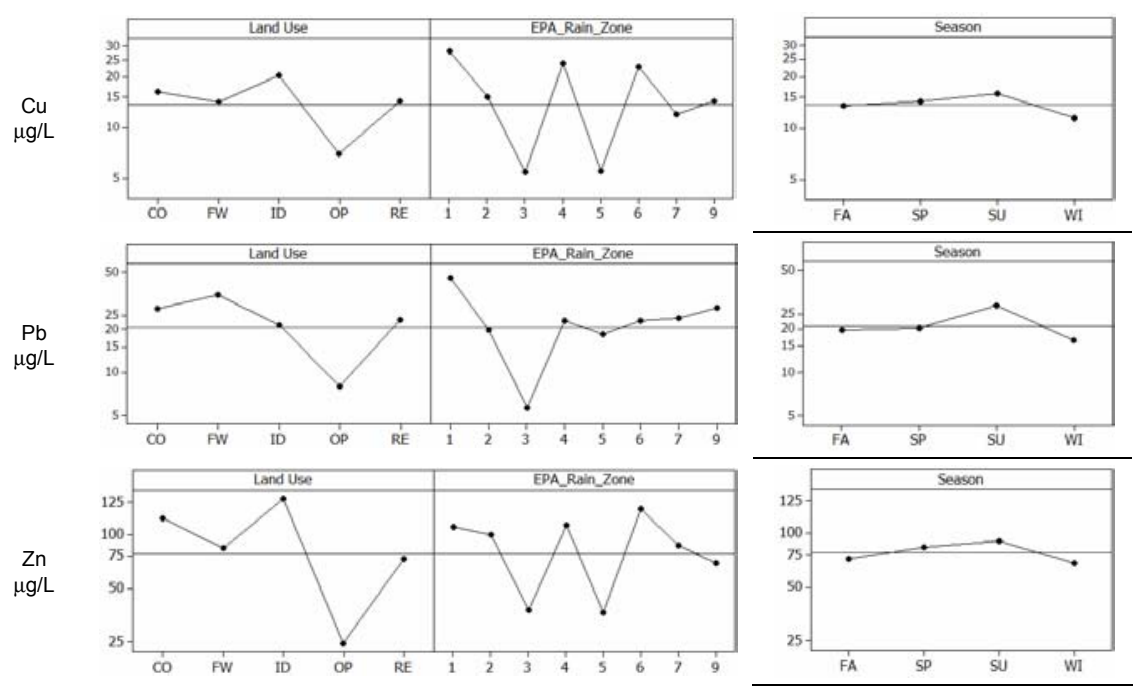

Figure 20. 7 (continued) Main factors plots for land use, EPA rain zone and season.

Figure 20.7 shows the plots of the main factors from the GLM analyses. For all the constituents except TSS, concentrations in the open space land use were lower than for the other land uses. However, samples collected at freeways and industrial sites had the highest concentrations.

In contrast to the previous case when land use and geographical location interactions were ignored, there were no obvious changes in concentrations for the different seasons. However, total phosphorus and TKN appear to be high during the summer and low during the winter. No clear variations in concentration were observed between spring and fall.

Samples collected in EPA rain zone 3 (the southeast) had the lowest concentrations for all the constituents. The largest concentrations were observed in rain zone 6 (the southwest) followed by rain zones 1 (Great Lakes and northeast) and 4 (Mississippi valley).

\subsection{Conclusions}

Ignoring the interactions between land use and EPA rain zone can mislead the interpretation of the factors that affect stormwater concentrations around the continental U.S. The EPA rain zone factor followed by the interaction 
between EPA rain zone and the land use, and the factor representing land use alone were all significant when examining the variations in concentrations of the nine stormwater constituents evaluated.

Season alone is not a significant factor in the variability of stormwater concentrations. However, the interaction between season and EPA rain zone is significant for all the standard pollutants except for TSS and total lead.

The concentrations of lead in stormwater concentrations have significantly reduced since the elimination of lead in gasoline.

The introduction of three-way catalytic converted may be related to the elevated ammonia and nitrate concentrations in stormwater samples collected at freeway sites.

The variability between sampling locations for any land use category is greater than the variability between land uses, signifying the need to have many sampling sites to represent each land use category for any one geographical area. It is expected that around $5 \%$ to $20 \%$ of the sites located in the same EPA rain zone and land use will have median concentrations that are significantly different than the remaining sites in the group. The smallest variability is expected in industrial drainage areas.

\section{Acknowledgments}

We would like to thank all the NPDES phase I municipalities that submit the results from their monitoring efforts to be included in the NSQD database, and to the EPA for sponsoring our efforts in compiling the database, under the direction of Bryan Rittenhouse. We also thank Jane Clary from Wright Waters Engineers for her assistance in obtaining the data from the International BMP Database, and Marcus Quigley and Stephen George from Geosyntec Consultants for their significant comments to this document. We also thank the students at the University of Alabama and the Center of Watershed Protection that assisted in reviewing and storing the stormwater data in the NSQD database.

\section{References}

American Society of Civil Engineers (ASCE), United States Environmental Protection Agency (EPA). 2000. Determining Urban Stormwater Best Management Practice (BMP) Removal Efficiencies. Task 3.4 Final Data Exploration and Evaluation Report. Office of Water. Washington D.C. 
American Society of Civil Engineers (ASCE), United States Environmental Protection Agency (EPA). 2002. Urban Stormwater BMP Performance Monitoring. A Guidance Manual for Meeting the National Stormwater BMP Database Requirements. Office of Water. Washington D.C. EPA

Berthouex P., Brown L. 2002. Statistics for Environmental Engineers. Boca Raton, Florida : Lewis Publishers.

Burton A., Pitt R. 2002. Stormwater Effects Handbook. A Toolbox for Watershed Managers, Scientists, and Engineers. Boca Raton, Florida : Lewis Publishers.

Driver, N.E., Mustard, M.H., Rhinesmith, R.B., and Middleburg, R.F. 1985. U.S. Geological Survey Urban Stormwater Database for 22 Metropolitan Areas Throughout the United States. U.S. Geological Survey Open File Report 85-337. Denver, CO: USGS

Fraser M. and Cass G. 1998. Detection of Excess Ammonia Emissions from In-Use Vehicles and the Implications for Fine Particle Control. Environmental Science and Technology (32) : 1053 - 1057

Gibbons J., Chakraborti S. 2003. Nonparametric Statistical Inference. New York, NY: Marcel Dekker Inc.

Kottegoda N.T. and Rosso R. 1998. Statistics, Probability and Reliability for Civil and Environmental Engineers. New York, NY: WCB McGraw-Hill.

Maestre, A., R.E. Pitt, S. Durrans and S. Chakraborti. 2005. "Stormwater Quality Descriptions using the Three Parameter Lognormal Distribution." Journal of Water Management Modeling R223-13. doi: 10.14796/JWMM.R223-13.

Maestre A. 2005. Stormwater Characteristics as Described in the National Stormwater Quality Database. Ph.D. Dissertation. Department of Civil and Environmental Engineering, University of Alabama. Tuscaloosa, Alabama.

National Council of the Paper Industry for Air and Stream Improvement (NCASI). 1995. A Statistical Method and Computer Program for Estimating the Mean and Variance of Multi-level Left Censored Data Sets. Technical Bulletin No. 703.

Pitt R. 1987. Small Storm Urban Flow and Particulate Washoff Contributions to Outfall Discharges. Ph.D. Dissertation. Department of Civil and Environmental Engineering, University of Wisconsin. Madison, Wisconsin.

Pitt, R., Maestre A., and Morquecho R. 2003. Evaluation of NPDES Phase I Municipal Stormwater Monitoring Data. In: National Conference on Urban Stormwater: Enhancing the Programs at the Local Level. EPA/625/R-03/003

Pitt, R.E., A. Maestre, R. Morquecho and D. Williamson. 2004. "Collection and Examination of a Municipal Separate Storm Sewer System Database." Journal of Water Management Modeling R220-13. doi: 10.14796/JWMM.R220-13.

Smullen, J.T. and Cave K.A. 2002. National Stormwater Runoff Pollution Database. In: Wet-Weather Flow in the Urban Watershed (Field, R., and D. Sullivan. Ed.). Boca Raton, Florida: Lewis Publishers.

Sutherland R., Tolusa C. 2000. Multi-element Analysis of Road-Deposited Sediment in an Urban Drainage Basin, Honolulu, Hawai. Environmental Pollution (110): 483-495

United States Environmental Protection Agency (EPA). 1983. Results of the Nationwide Runoff Program. Water Planning Division, PB 84-185552. Washington D.C: EPA 
United States Environmental Protection Agency (EPA). 1986. Methodology for Analysis of Detention Basins for Control of Urban Runoff Quality. Office of Water, Nonpoint Source Division. Washington D.C: EPA

United States Environmental Protection Agency (EPA). 2003. Stormwater Outreach Materials: After the Storm Brochure. Office of Water Management, EPA 833-B-03002. Washington D.C: EPA

United States Environmental Protection Agency (EPA). 2003. Stormwater Outreach Materials: Make Your Home the Solution to Stormwater Pollution Brochure. Office of Water Management, EPA 833-B-03-003. Washington D.C: EPA

Van Buren M., Watt A., Marsalek J. 1997. Application of the Lognormal and Normal Distribution to Stormwater Quality Parameters. Water Research 31 (1): 95 - 104 
